NBER WORKING PAPER SERIES

\title{
SHRINKING THE TAX GAP: APPROACHES AND REVENUE POTENTIAL
}

\author{
Natasha Sarin \\ Lawrence H. Summers \\ Working Paper 26475 \\ http://www.nber.org/papers/w26475 \\ NATIONAL BUREAU OF ECONOMIC RESEARCH \\ 1050 Massachusetts Avenue \\ Cambridge, MA 02138 \\ November 2019
}

We are grateful to Joe Kupferberg for excellent research assistance. We thank Jason Furman, Michael Knoll, John McClelland, Leslie Samuels, and Charles Rossotti for helpful conversations. The views expressed herein are those of the authors and do not necessarily reflect the views of the National Bureau of Economic Research.

NBER working papers are circulated for discussion and comment purposes. They have not been peer-reviewed or been subject to the review by the NBER Board of Directors that accompanies official NBER publications.

(C) 2019 by Natasha Sarin and Lawrence H. Summers. All rights reserved. Short sections of text, not to exceed two paragraphs, may be quoted without explicit permission provided that full credit, including $\odot$ notice, is given to the source. 
Shrinking the Tax Gap: Approaches and Revenue Potential

Natasha Sarin and Lawrence H. Summers

NBER Working Paper No. 26475

November 2019

JEL No. H0,H2,H26

\begin{abstract}
$\underline{\text { ABSTRACT }}$
Between 2020 and 2029, the IRS will fail to collect nearly \$7.5 trillion of taxes it is due. It is not possible to calculate with precision how much of this "tax gap" could be collected. This paper offers a naïve approach. The analysis suggests that with feasible changes in policy, the IRS could aspire to shrink the tax gap by around 15 percent in the next decade-generating over $\$ 1$ trillion in additional revenue by performing more audits (especially of high-income earners), increasing information reporting requirements, and investing in information technology. These investments will increase efficiency and are likely to be very progressive.
\end{abstract}

Natasha Sarin

University of Pennsylvania

Carey Law

Silverman 139

3501 Sansom Street

Philadelphia, PA 19104

nsarin@law.upenn.edu

Lawrence H. Summers

Harvard Kennedy School of Government

79 JFK Street

Cambridge, MA 02138

and NBER

lhs@ harvard.edu 


\section{Shrinking the Tax Gap: Approaches and Revenue Potential}

\section{Natasha Sarin and Lawrence H. Summers}

The IRS recently released its most recent estimates on the tax gap- the difference between what was due to the IRS and what it collected. ${ }^{1}$ Between 2011 and 2013, the IRS estimates that it failed to collect over $\$ 380$ billion in taxes per year, across all tax categories.

Extrapolating this estimate to present to allow for inflation and income growth, in 2020 the IRS will fail to collect over $\$ 630$ billion, or nearly 15 percent of total tax liabilities and that the tax gap will total $\$ 7.5$ trillion over the 2020 to 2029 period. ${ }^{2,3}$ The sheer magnitude of the tax gap suggests that there is substantial revenue-raising potential from shrinking it through welltargeted enforcement measures.

It is not possible to calculate with precision how much of this missing $\$ 7.5$ trillion could be collected. Our estimates suggest that it is reasonable to anticipate that with feasible changes in policy, the IRS could aspire to shrink the tax gap by around 15 percent. ${ }^{4}$ This would require increased investment in compliance efforts, in the range of previous IRS budget outlays. On the assumption of immediate implementation, our estimates suggest it would be possible to generate around $\$ 1.1$ trillion in additional revenue in a decade. ${ }^{5}$

This short article represents an attempt to quantify the benefits of substantial investment in tax compliance. We proceed in three parts. We first provide background on the tax gap, noting that the benefits of noncompliance accrue most to high-income earners; and that the resources

\footnotetext{
${ }^{1}$ IRS Publication 1415, “Federal Tax Compliance Research: Tax Gap Estimates for Tax Years 2011-2013” (Sept. 2019).

${ }^{2}$ To get this number, we first estimate the 2018 tax gap, assuming the net compliance rate of 85.8 percent from the most recent IRS projections as follows: Taxes Owed = Gross Collections/Net Compliance Rate; and Tax Gap = Taxes Owed - Gross Collections. We then age this total to 2020 using the CBO's projected nominal growth rates for 2018 (5.4 percent) and 2019 (4.3 percent). Our sources are CBO, “The Budget and Economic Outlook, 2019-2029” (Jan. 2019); SOI Tax Stats: Gross Collections by Type of Tax: IRS Data Book Table 6; and IRS Publication 1415, supra note 1.

${ }^{3}$ To extrapolate our estimates, we rely on the most recent CBO budget projections, which report that average nominal GDP growth will be around 3.85 percent annually between 2020 and 2029. CBO, supra note 2, at Table 2.3, “CBO’s Economic Projections for Calendar Years 2019-2029.” We use this approach for all extrapolations to the decade 2020-2029.

${ }^{4}$ Between $\$ 750$ billion and $\$ 1.1$ trillion between 2020 and 2029.

${ }^{5}$ Since we prepared this paper, Senator Warren released her Medicare for All proposal, which includes \$2.3 trillion in additional federal revenue from tax compliance efforts. We note that if we have made errors in the estimation offered, we believe they are more likely to be on the side of optimism than pessimism.
} 
the IRS has at its disposal to tackle noncompliance are at historic lows. This suggests that there is substantial low-hanging fruit to be gathered from adequate investment in the IRS, and that investments in reducing noncompliance are likely to be progressive. We then argue that more resources for examinations (particularly of high-income earners); an increase in cross-party reporting requirements; and an overhaul of outdated IRS technology will enable the IRS to shrink the tax gap by around 15 percent in the next decade. These estimates seem substantially optimistic relative to what the CBO estimates an increase in IRS appropriations would raise; however, we show the two can be reconciled. Further, we point out that agency scorekeeping guidelines disincentivize compliance investment by limiting the extent to which the gains from additional tax collections can be included in official scores of enforcement initiatives. We conclude by noting that our estimation is naïve and that more formal revenue estimates are desirable. However, we find it probably that scorekeepers will come to the same basic conclusion: restoring the IRS' budget to previous levels is likely to pay for itself many times over.

\section{Background on the tax gap}

\section{a. Tax gap benefits primarily high-income earners}

In each filing category—for individual income, corporate income, employment, ${ }^{6}$ and estate tax filers, the majority of the benefits of noncompliance accrue to high-income earners. Individual tax returns make up the largest share of the tax gap (over 70 percent) and have the highest rate of noncompliance (nearly 20 percent). ${ }^{7}$ The sources of the individual income tax gap are primarily high-income individuals because more of their income accrues in opaque categories, like dividend income, capital gains, and proprietorship income. In some of these categories, taxes are only paid on 55 percent of income earned.

\footnotetext{
${ }^{6}$ Employment taxes include withheld Social Security and Medicare taxes, federal unemployment taxes, and selfemployment taxes (Social Security and Medicare taxes owed by individuals who work for themselves). See IRS Publication 1415, supra note 1, at section 4.2.3, "Employment Tax Underreporting Tax Gap.”

${ }^{7}$ Between 2011 and 2013, the net tax gap for individual income taxes averaged \$271 billion. Total true tax liability averaged \$1,398 billion. So there was a 19.4 percent net non-compliance rate. Id.
} 


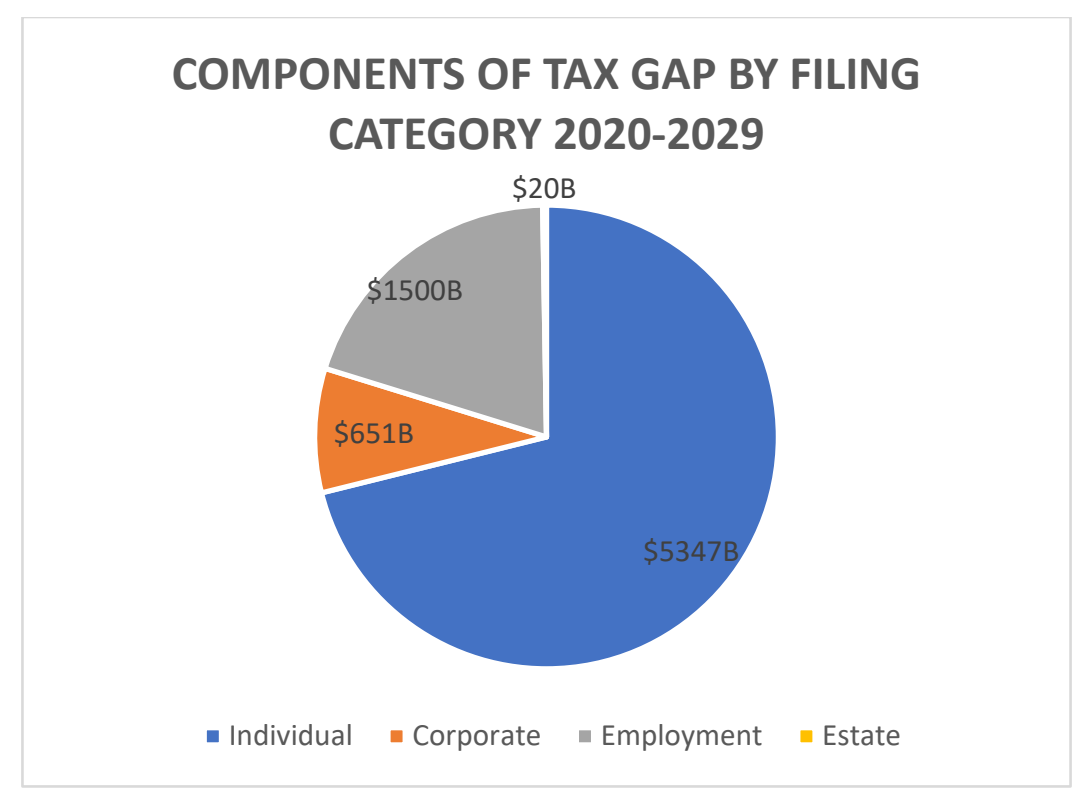

Figure 1: 2020-2029 Projected Tax Gap by Filing Category ${ }^{8}$

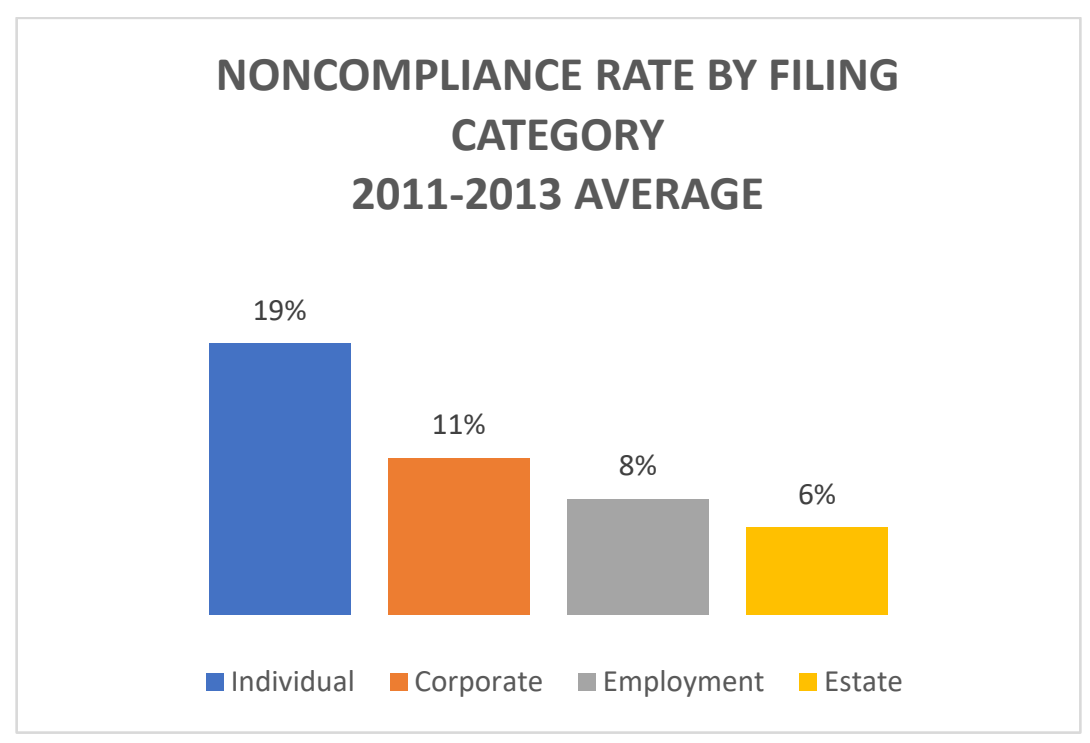

Figure 2: Noncompliance by Filing Category ${ }^{9}$

\footnotetext{
${ }^{8}$ IRS Publication 1415, “Federal Tax Compliance Research: Tax Gap Estimates for Tax Years 2011-2013” (Sept. 2019). The employment tax gap includes both underpaid employment and self-employment taxes. To compute the tax gap for 2020-2029, we first take the share of the gross tax gap for which the IRS reports each filing category was responsible between 2011 and 2013. We apply these shares to our estimate of the overall net tax gap for 2020-2029. ${ }^{9}$ Id.
} 
We illustrate this point below using data on individual income filers' underreporting rates, which are available by category of income. Underreporting accounts for around 80 percent of the total tax gap (the remaining 20 percent comes from non-filing or under-payment of taxes due). ${ }^{10}$ In Table 1, we attempt a rough estimation of misreporting rates by income level. We compute average underreporting rates for individual filers based on the share of their income that accrues to them in each of the available individual income categories. Underreporting is more than five times as high for individuals who earn \$10 million or more annual than it is for those who make under $\$ 200,000$ a year.

\begin{tabular}{|l|c|}
\hline & $\begin{array}{c}\text { Average } \\
\text { underreporting } \\
\text { percentage }\end{array}$ \\
\hline Under $\$ 200,000$ & $2.6 \%$ \\
\hline$\$ 200,000$ under $\$ 500,000$ & $4.5 \%$ \\
\hline$\$ 500,000$ under $\$ 1,000,000$ & $6.7 \%$ \\
\hline$\$ 1,000,000$ under $\$ 5,000,000$ & $9.1 \%$ \\
\hline$\$ 5,000,000$ under $\$ 10,000,000$ & $11.1 \%$ \\
\hline$\$ 10,000,000$ or more & $13.9 \%$ \\
\hline
\end{tabular}

Table 1: Average Net Misreporting for Individual Income Tax Filers by Income Level ${ }^{11,12}$

\footnotetext{
${ }^{10}$ Unfortunately, data on noncompliance by income category is only reported for the "underreporting” tax gap, not for non-filing or under-payment. As such, the information in Tables 1 and 2, infra, relies on data on the underreporting tax gap. For ease of discussion, we assume that noncompliance rates overall across income categories are comparable to misreporting rates for underreported income.

${ }^{11}$ To arrive at this average, we multiply the share of income that accrues in each income category from Table 1 by the net misreporting percentage for income in that category reported by the IRS. For example, individuals who make $\$ 10$ million $+\approx 17 \%$ income from salary and wages x $1 \%$ misreporting $+13 \%$ dividends x 5\% misreporting $+18 \%$ partnership x $11 \%$ misreporting $+47 \%$ capital gains x $23 \%$ misreporting.

${ }^{12}$ At first glance it may appear surprising that the average underreporting percentages broken down by income category are each less than the headline $18 \%$ underreporting across individual filers. This is in fact expected and reflects the difficulty in such a calculation. The approach to calculating these percentages normalizes by a mass greater than 100 percent of taxable filer income; in the case of offsets and losses, the subcategories are calculated as underreported amount divided by the absolute value of quantities that should have been reported. We also lack information on underreporting for every individual income category, so necessarily omit some individual income. Our weights are also constructed from reported income. Ideally, we would do this exercise with true income, as this approach underweights categories with the highest underreporting percentages.
} 
Statistics on reporting rates for other filing categories-like corporate taxes, employment taxes (e.g., social security and Medicare taxes, for employers and those self-employed), and estate taxes - are not available by income level. However, it seems likely that the beneficiaries of tax evasion for other types of tax filers are also disproportionately the wealthy. ${ }^{13}$ In the case of corporate taxes, Treasury and JCT estimate that at least 75 percent of the burden of the corporate tax falls on corporate shareholders or owners of capital (Cronin et al. 2012, JCT 2013). And only estates of the wealthiest 0.1 percent are even eligible for estate taxation, meaning they are the sole beneficiaries of the $\$ 1.5$ billion in estimated annual estate tax avoidance. ${ }^{14}$

\section{b. IRS resources to tackle noncompliance declining over time}

While it is true that outright elimination of any tax gap is impossible, the magnitude of the gap between what is due and what the IRS collects is a function of the resources at its disposal to detect and punish individuals, firms, estates, and tax avoiders across other filing categories. These resources have decreased over time: The IRS budget has decreased (in real terms) by nearly 15 percent since 2011. Its enforcement budget has dropped by 25 percent during this period. Another way to appreciate the extent to which the IRS today is handicapped relative to longer-term historical norms comes from examining its budget as a share of gross collections. The share of tax revenue that is reinvested in the IRS has decreased steadily over the last twentyfive years, from its peak of 0.6 percent in 1993 to its trough of 0.34 percent today. ${ }^{16}$ Since 2011, the ratio of its budget to collection activity fell by 34 percent. ${ }^{18}$ This results in sizeable direct

\footnotetext{
${ }^{13}$ We are unaware of estimates of the incidence of employment tax noncompliance. High-income earners avoid employment taxes by setting up passthrough businesses, and estimates suggest that over 10 percent of gig economy workers simply do not report their income for tax purposes.

${ }^{14}$ In 2018, the number of estates eligible for estate taxation fell to less than 2,000 (from around 5,000 previously). See Howard Gleckman, “Only 1,700 Estates Would Owe Estate Tax in 2018 Under the TCJA,” Urban-Brookings Tax Policy Center (Dec. 6, 2017); and Heather Long, “3,200 Wealthy Individuals Wouldn’t Pay Estate Tax Next Year Under GOP Plan,” The Washington Post, Nov. 11, 2017.

${ }^{16}$ Considering the IRS budget as a share of gross collections is potentially problematic because changes in the tax code will impact collections, and so the decrease we observe could hypothetically be related to an increase in owed tax liabilities. To alleviate this concern, we also look at the IRS budget as a share of cumulative adjusted gross income for all individual filers. This too reflects a similar trend, decreasing from a peak of 0.16 percent in 1996 to 0.11 percent in 2016 (the last year for which this data is available).

${ }^{18}$ The earliest year these data are available in the IRS Data Book Index of Tables. For some series, historical data exist in the SOI Tax Stats Archive. Unless we refer to it explicitly, our focus is on data that is available in the IRS Data Book Index of Tables, not the historical archives. The budget data come from IRS Data Book Table 28: "Costs Incurred by Budget Activity." In real terms, the IRS budget has been above the FY 2018 level every year since 2001. Unless noted otherwise, dollar estimates are presented in 2018 dollars. Data on real GDP comes from FRED.
} 
losses to the IRS. But such a lax enforcement regime also has sizable indirect effects, as previously law-abiding filers realize that there are substantial gains—and little cost—-to noncompliance.

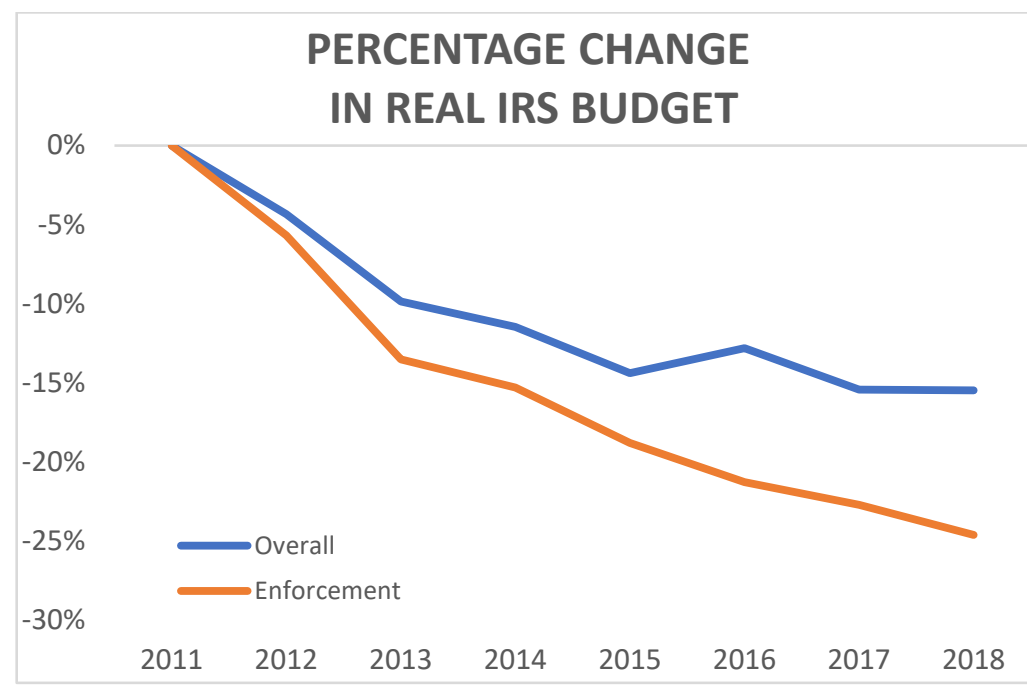

Figure 3: Percentage Change in IRS Budget ${ }^{20}$

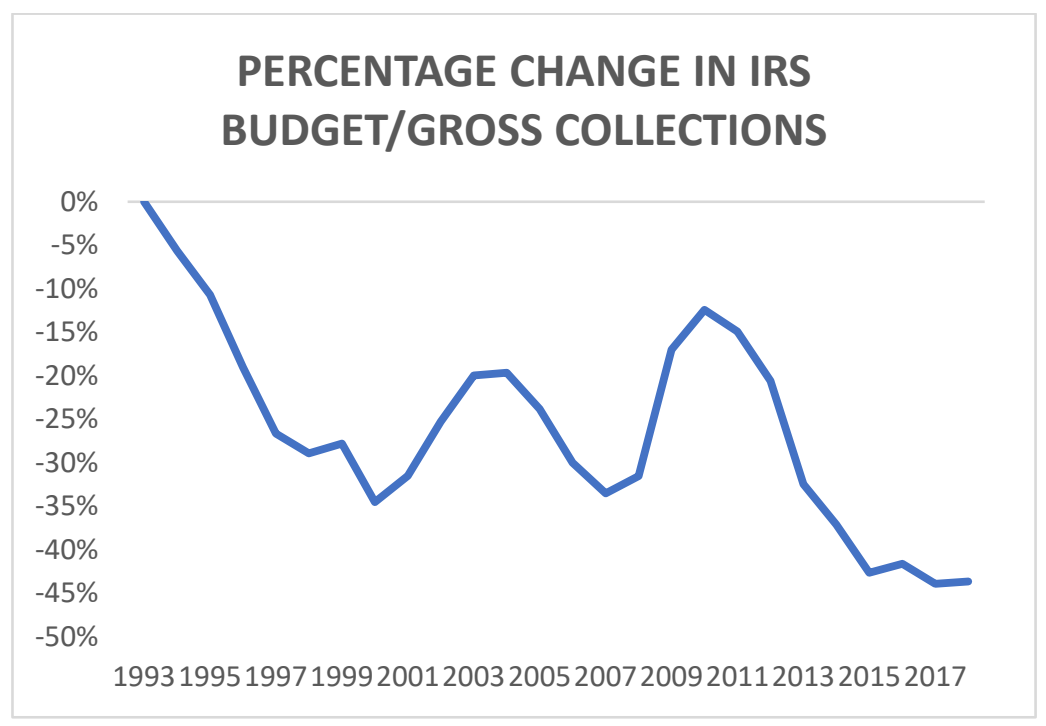

Figure 4: Percentage Change in IRS Budget as a Share of Collections ${ }^{21}$

\footnotetext{
${ }^{20}$ IRS SOI Tax Stats, Table 28: Costs Incurred by Budget Activity. For each year, we convert overall budget and enforcement budget to 2018 dollars. For years 2011 to 2018, percentage change relative to 2010 is reported.

${ }^{21}$ IRS SOI Tax Stats, Table 29: Collections, Costs, Personnel, and US Population. For each year from 1993 to 2018, we calculate the ratio between IRS operating costs and gross collections. For years 1994 to 2018, the percentage change in this ratio relative to 1993 is reported.
} 
Because of this decrease in enforcement resources, today, the IRS has fewer auditors than it had at any point since World War II. Last year the IRS' criminal division brought fewer than 800 cases in which tax fraud was the primary crime, a decline of almost 25 percent over this decade. ${ }^{22}$ Its workforce declined by essentially this proportion over this same period.

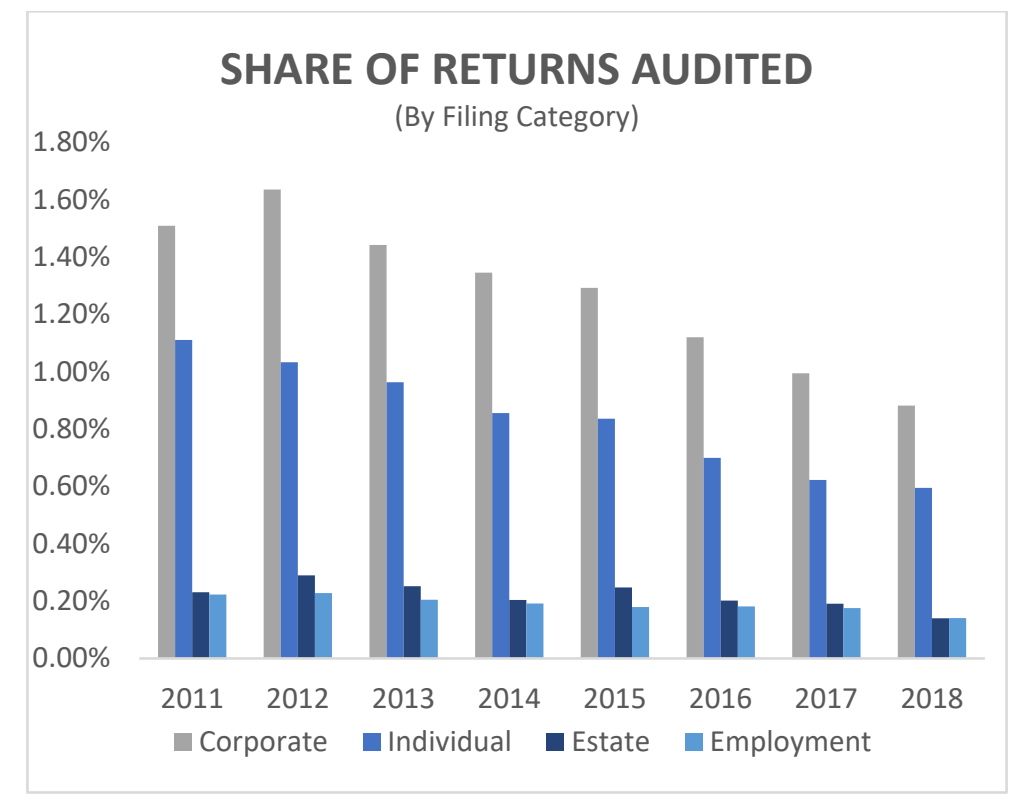

Figure 5: Share of Returns Audited by Filing Category ${ }^{23}$

Consequently, the share of returns that are examined declined by around 45 percent since 2011. There has been a steep decline across filing categories: the share of individual returns, corporate returns, employment returns, and estate returns examined decreased by between 37 percent and 46 percent during this period.

One might argue that a reduction in enforcement resources is benign for multiple reasons. First, it is plausible that as technological developments have made the IRS more efficient, such that it no longer needs large outlays to police tax evasion. Second, if the IRS successfully targets resources toward examining the most egregious evaders' returns, then a steep decline in the share of audits performed will have a much lesser impact on audit revenue.

\footnotetext{
${ }^{22}$ Jesse Eisenger and Paul Kiel, “After Budget Cuts, the IRS’ Work Against Tax Cheats is Facing 'Collapse,’” ProPublica, Oct. 1, 2018.

${ }^{23}$ IRS SOI Tax Stats. Table 9a: Examination Coverage: Recommended and Average Recommended Additional Tax After Examination.
} 
The fact that we observe an essentially 1:1 relationship between the resources that the IRS has at its disposal and the revenue generated from examinations casts doubts on these theories. As Figure 6 illustrates, since 2011, the share of returns audited (across all filing categories) fell by 45 percent, and the additional taxes collected from audits fell by nearly 50 percent. The same is true for audits of high-income individual returns, which generate substantial revenue for the IRS: audit rates for individuals making \$1 million or more annually peaked in 2011 at 12.5 percent. Since then, they have fallen: Last year, only 3.2 percent of returns of these high-income individuals were audited. Consequently, the additional revenue generated from examination of millionaires’ individual income tax filings declined by a similar amount (70 percent) over this period. These patterns suggest that it is unlikely that there would be diminishing returns to a substantial increase in IRS examination resources.

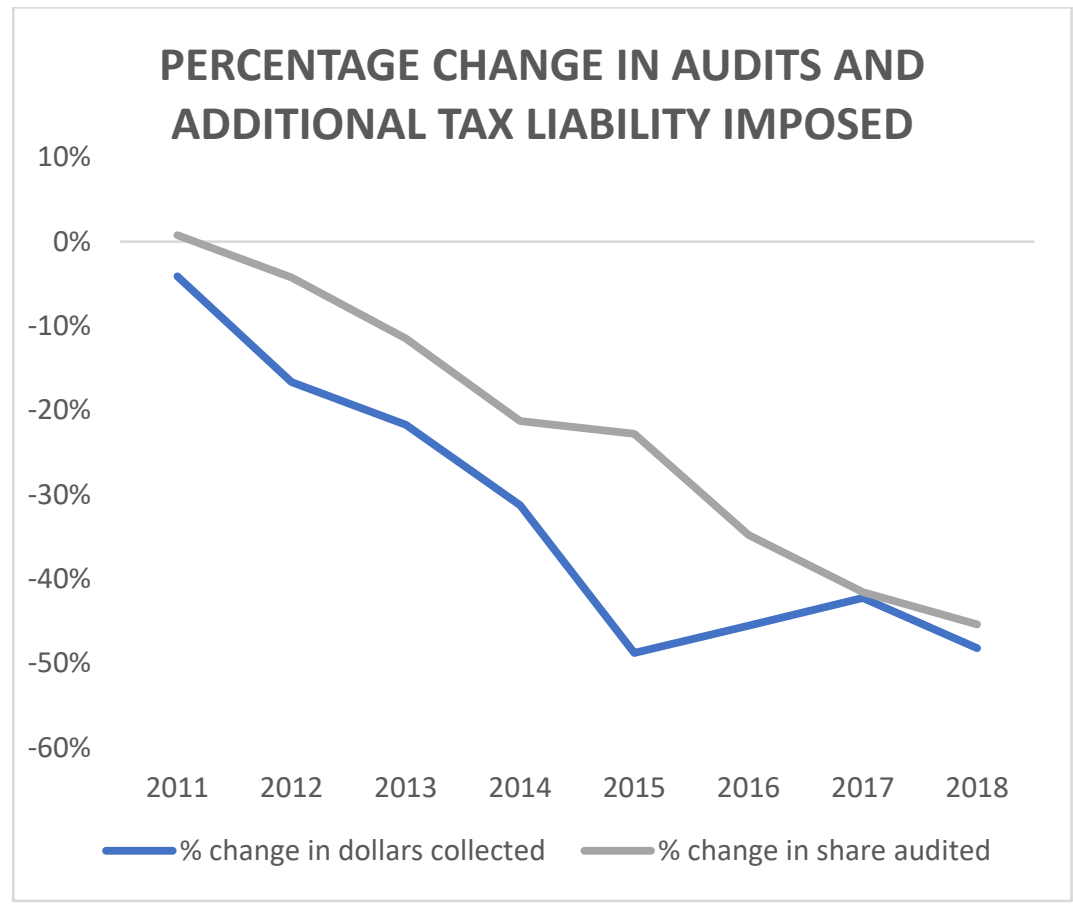

Figure 6: Examination Coverage and Recommended Taxes Post-Examination, Overall ${ }^{24}$

\footnotetext{
${ }^{24}$ IRS SOI Tax Stats. Table 9a: Examination Coverage: Recommended and Average Recommended Additional Tax After Examination. For each year, we convert additional tax liability to 2018 dollars. For both audit levels and additional tax liability, in years 2011 to 2018, percentage change relative to 2010 is reported. Note that these estimates are for additional tax liability imposed post-examination; and do not include civil penalties assessed to tax evaders.
} 


\section{Potential reforms}

Below, we estimate the revenue-raising potential of specific reforms to shrink the tax gap by (1) increasing enforcement resources and targeting high-income individuals for audit scrutiny; (2) improving information reporting; and (3) greater IT investments. It seems likely that these changes could raise over $\$ 1$ trillion in the coming decade, shrinking the tax gap by around 15 percent.

\begin{tabular}{|lr|}
\hline $\begin{array}{lr}\text { Tax Gap (billion dollars) } \\
\text { Approaches to shrink tax gap }\end{array}$ & $\$ 7.5$ trillion \\
\hline (1) Enhanced enforcement resources & $\$ 715$ billion \\
(2) Improved information reporting & $\$ 350$ billion \\
(3) IT investment & $\$ 100$ billion \\
\hline Total revenue raised & $\sim \$ 1.15$ trillion \\
Percent decrease in tax gap, net of costs & $15 \%$ \\
\hline
\end{tabular}

Table 2: Summary of Revenue Raising Potential of Compliance Efforts

\section{a. Increasing examination rates}

\section{i. Increasing examination rates for individual income tax filers}

The likelihood that an individual return will be audited has been falling since 2011, when it peaked at 1.1 percent. Last year, only 0.5 percent of individual returns were audited.

Had audits last year been performed at 2011 rates, the IRS would have audited 775,000 more individual returns. This would have generated nearly $\$ 14$ billion in additional revenue in 2018, and around $\$ 180$ billion in additional revenue if audit rates were at this level for the coming decade (2020 to 2029). ${ }^{25}$

\footnotetext{
${ }^{25}$ To get this estimate, we take 2011 average revenue per audit (additional tax liability + civil penalties, net of abatements) x 775,000 additional individual audits. This gives us an estimate of how much additional revenue would have been collected in 2018 if audit rates were at the 2011 peak. We then extrapolate for years 2020 to 2029 to adjust for growth and inflation as described in note 2, supra.
} 
Revenue potential of return to 2011 individual audit rates

\begin{tabular}{lc}
\hline A. Additional 2018 audits & 775,000 \\
B. Revenue raised per audit & $\$ 17,900$ \\
& \\
Additional 2018 revenue (A x B) & $\$ 14$ billion \\
Additional 2020 to 2029 revenue & $\$ 180$ billion \\
\hline
\end{tabular}

Table 3: Revenue raised from returning to historical individual audit levels

This understates the revenue-raising potential of adequate and appropriately targeted enforcement resources because it does not account for the efficiency gains from tilting individual audits toward high-income earners, where returns on investment are highest, as described above. Had the IRS audited individuals in 2018 at 2011 rates, nearly 95 percent of this increase in individual examinations would have been audits of those making $\$ 200,000$ or less a year, who are primarily ordinary wage earners with near-perfect compliance. Audit rates for multimillionaires would remain at low levels: around 8 percent for the 30,000 individuals making \$5 million to \$10 million; and 12.5 percent for the 15,000 individuals making \$10 million or more. ${ }^{26}$

Increasing the IRS's enforcement resources would substantially increase tax collections. But reconsideration of how the recourses at its disposal are allocated would also be consequential. In 2013, the IRS estimated that an extra hour spent auditing someone who earns $\$ 200,000$ annually generated only $\$ 650$. An extra hour spent auditing someone who makes \$5 million or more a year generated around $\$ 4,900 .{ }^{27}$ It is thus hard to explain from an efficiency

\footnotetext{
${ }^{26}$ IRS SOI Tax Stats. Table 9a: Examination Coverage: Recommended and Average Recommended Additional Tax After Examination, by Type of Return; Table 9b: Individual Income Tax Returns Examined; Table 17: Civil Penalties Assessed and Abated, by Type of Tax and Type of Penalty. To calculate this estimate, we use data from Table $9 \mathrm{~b}$ to calculate the share of total audits performed within an income category in 2018. We then take the total number of additional audits that would be performed if the IRS returned to 2011 individual audit levels, and distribute it throughout the income distribution based on 2018 examination shares.

${ }^{27}$ Treasury Inspector General for Tax Administration J. Russell George, "Understanding the Tax Gap and Taxpayer Noncompliance” (May 9, 2019) (House Ways and Means testimony). Estimates adjusted to 2018 dollars.
} 
perspective why in 2018 individuals who made \$500,000 or more were audited at similar rates as EITC recipients whose top income is below $\$ 50,000 .{ }^{28,29}$

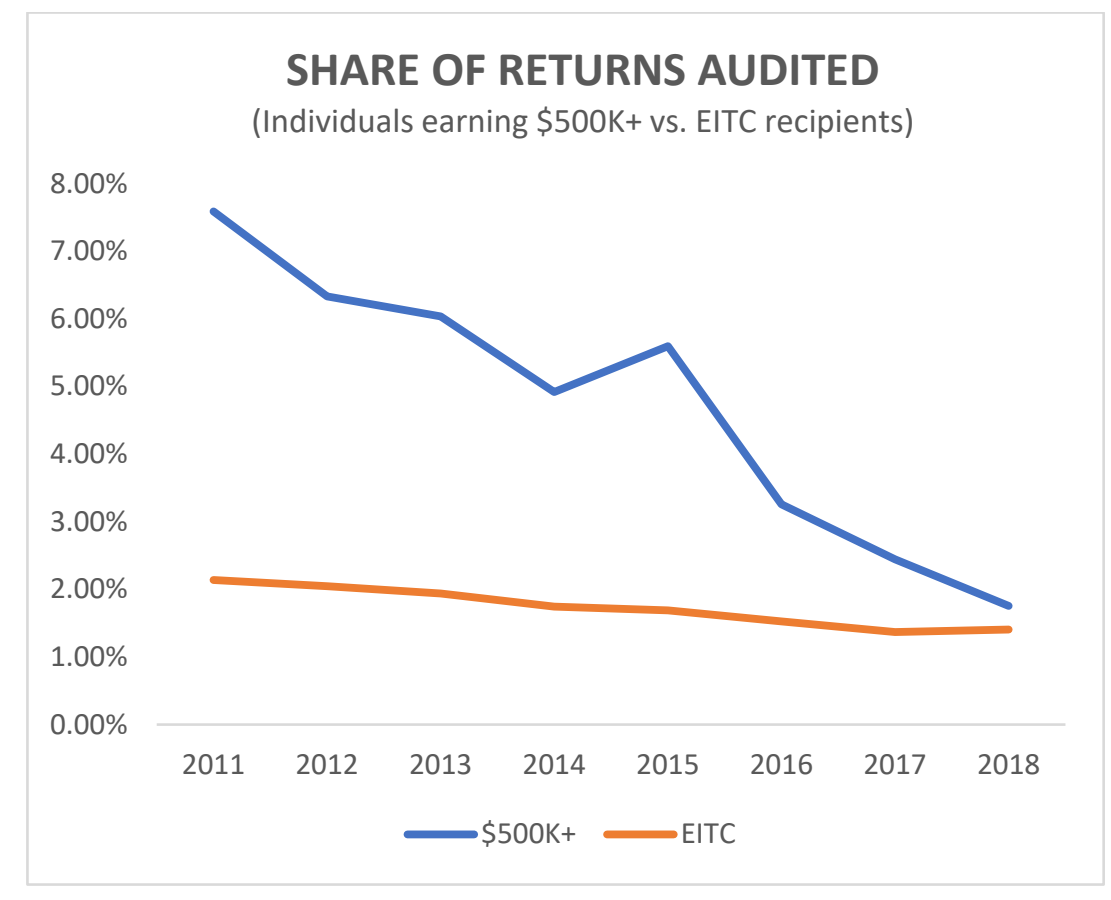

Figure 7: Audit rates for those earning over $\$ 500,000$ annually vs. EITC recipients ${ }^{30}$

To understand the revenue-raising potential of focusing examination resources on highincome earners, consider the following: The IRS spent over \$8 billion last year on its 75,000person workforce. ${ }^{31}$ Assuming a forty-hour workweek, the average IRS employee makes around \$55 per hour. Even if overhead costs relating to audits of individuals who make \$1 million or more annually are five times this size, an extra hour spent auditing a high-income individual amounts to a 1,800 percent return on investment.

\footnotetext{
${ }^{28}$ The IRS recently reported to Congress that high numbers of EITC audits are in fact the most efficient use of the current resources at the agency's disposal because EITC audits are conducted mostly via mail and performed by less-skilled auditors. Audits of the wealthy require senior specialists that the IRS has had trouble retaining. Thus, before more high-income audits can be performed, "Congress must fund and the IRS must hire and train appropriate numbers" of skilled, senior auditors capable of examining complex returns. Letter from IRS Commissioner Charles P. Rettig to Sen. Ron Wyden, D-ORE, ranking Finance Committee member (Sept. 6, 2019). Committee on Finance. United States Senate. September 6, 2019.

${ }^{29}$ In 2019 for a single head of household, to claim EITC income must be less than \$50,162. IRS, "2019 EITC Income Limits, Maximum Credit Amounts and Tax Law Updates” (July 10, 2019).

${ }^{30}$ IRS SOI Tax Stats. Table 9a: Examination Coverage: Recommended and Average Recommended Additional Tax After Examination, by Type of Return; Table 9b: Individual Income Tax Returns Examined.

${ }^{31}$ IRS SOI Tax Stats. Table 28: Costs Incurred by Budget Activity, Table 30: Personnel Summary, by Employment Status, Budget Activity, and Selected Type of Personnel.
} 
This large payoff to high-income audits has several components: (1) first, mechanically, those who are wealthier have larger tax liabilities and so discrepancies between what is owed and what is paid tend to be larger in magnitude; (2) second, high net-worth individuals have more complex returns, and their income tends to accrue in opaque categories where information reporting, and thus compliance, is lowest; and (3) high income individuals have the most motivation and resources to invest in lowering tax liability.

Given the significant returns from audits of high-income individuals, imagine that the IRS directs new examination resources to focus on these returns: auditing 50 percent of individuals who make $\$ 10$ million or more; 33 percent of those who make between $\$ 5$ million and \$10 million; and 20 percent of those who make $\$ 1$ million or more. In 2018, this would have corresponded to roughly 70,000 additional audits of those earning $\$ 1$ million or more annually.

Because the returns of the high-income are most complex, these examinations are most costly and most time-consuming. ${ }^{32}$ We thus assume that it takes ten times as long to audit someone above the millionaire threshold as someone below. Thus, instead of restoring audit rates for those earning $\$ 200,000$ or less annually to 2011 levels; consider a scenario where the IRS instead increases audit rates for those earning $\$ 1$ million or more annually. This would have generated nearly $\$ 41.5$ billion in additional revenue in 2018. If these additional examinations are performed between 2020 and 2029, the additional tax revenue collected from this approach would be nearly $\$ 535$ billion.

\footnotetext{
${ }^{32}$ They can also only effectively be performed by the skilled senior auditors, "revenue agents" who are the IRS' "most highly trained and experienced employees with substantial accounting skills." The average time to complete an audit of an individual making \$10 million or more annually is in the range of 50 to 250 hours. Rettig letter, supra note 28.
} 


\begin{tabular}{|lcc|}
\hline \multicolumn{3}{|c|}{ Additional revenue raised from greater enforcement (billion dollars) } \\
\hline & (1) 2018 if audit rates at 2011 levels & (2) 2018 if focus on high-income audits \\
Under $\$ 200,000$ & 6.6 & 0.0 \\
\$200,000 to \$1 million & 2.4 & 2.4 \\
$\$ 1$ million to \$5 million & 3.8 & 32.0 \\
$\$ 5$ million to \$10 million & 0.6 & 4.1 \\
Over \$10 million & 0.5 & 3.0 \\
\hline $\mathbf{2 0 1 8}$ total & 13.9 & 41.5 \\
$\mathbf{2 0 2 0}$ to 2029 total & $\sim 180$ & $\sim 535$ \\
\hline
\end{tabular}

Table 4: Revenue Raising Potential of Increasing Audits to 2011 Levels across Income Categories (Column 1); or Targeting Enforcement Resources to High Income Taxpayers (Column 2) ${ }^{33}$

\section{ii. Increasing examination rates for estate, employment, and corporate tax returns}

Had the IRS examined returns at 2011 levels last year, it would have also audited around 11,500 more corporations. Though less than 2 percent of the increase in individual audits (by number), these audits would have generated substantial revenue for the IRS, since in 2011, each corporate audit averaged around \$1 million in additional tax liability and civil penalties imposed.

\footnotetext{
${ }^{33}$ IRS SOI Tax Stats. Table 9a: Examination Coverage: Recommended and Average Recommended Additional Tax After Examination, by Type of Return; Table 9b: Individual Income Tax Returns Examined; Table 17: Civil Penalties Assessed and Abated, by Type of Tax and Type of Penalty. To arrive at these estimates in Column (1), from a return to audit rates at 2011 levels, we take the total across individual income categories estimated from returning to 2011 individual audit rates (around \$14 billion) and distribute it among income categories based on the share of additional tax liability each income group was responsible for in 2011. We divide this total by the number of additional audits that would be performed if the IRS returned to 2011 levels to arrive at an estimate for the average additional tax collection (inclusive of civil penalties) for each additional audit performed, by income level. Note that the distribution of additional tax liability is only available in broad income groups (under $\$ 200,000$, $\$ 200,000$ to $\$ 1$ million, over $\$ 1$ million). We thus are forced to assume that all audits of those earning over $\$ 1$ million generate equivalent average additional revenue. In Column (2), we use the average additional revenue per audit computed to evaluate the consequence of a shift toward higher-income auditing. Practically, because we assume an extra high-income audit will take 10 times as long as that of an individual earning $\$ 200,000$ or less annually, this means that rather than performing about 730,000 additional audits of low-income earners (as would be required to return to 2011 levels), the IRS instead performs only 3,600 additional low-income audits, shifting the vast majority of resources toward those earning over $\$ 1$ million.
} 
The audit rates for other filing categories, like estate and employment returns, have decreased substantially as well. Since 2011, the share of returns audited across all filing categories has fallen from $0.9 \%$ to $0.5 \%$. Increasing examination rates to 2011 levels for estate, employment, and corporate returns; as well as an increase in audits of individual tax filers, focused particularly on the high-income-could generate over $\$ 700$ billion in additional tax revenue between 2020 and 2029.

\begin{tabular}{|c|c|c|c|c|c|}
\hline & $\begin{array}{l}2011 \text { audit } \\
\text { rate }\end{array}$ & $\begin{array}{c}2018 \\
\text { audit } \\
\text { rate }\end{array}$ & $\begin{array}{l}\text { Extra } 2018 \text { audits } \\
\text { if } 2011 \text { rates }\end{array}$ & $\begin{array}{c}\text { Extra } 2018 \\
\text { revenue } \\
\text { (billions of } \\
\text { dollars) if } 2011 \\
\text { rates } \\
\end{array}$ & $\begin{array}{c}\text { Extra revenue } \\
2020-2029 \\
\text { (billions of } \\
\text { dollars) if } 2011 \\
\text { rates } \\
\end{array}$ \\
\hline $\begin{array}{l}\text { Individual income tax } \\
\text { filers, tilting to high- } \\
\text { income audits option }\end{array}$ & $1.1 \%$ & $0.6 \%$ & 130,732 & 41.5 & $\sim 535$ \\
\hline Corporate tax filers & $1.5 \%$ & $0.9 \%$ & 11,458 & 11.1 & $\sim 143$ \\
\hline Estate and trust income tax & $0.10 \%$ & $0.05 \%$ & 1,446 & 0.0 & $\sim 0.4$ \\
\hline Estate tax & $18.2 \%$ & $8.6 \%$ & 3,243 & 1.3 & $\sim 17$ \\
\hline Employment tax & $0.22 \%$ & $0.14 \%$ & 25,100 & 1.6 & $\sim 20.1$ \\
\hline $\begin{array}{l}\text { Total from } 2011 \text { audit } \\
\text { levels }\end{array}$ & & & & 55.6 & $\sim 715$ \\
\hline
\end{tabular}

Table 5: Revenue Raising Potential of Increased Examinations across Different Tax Types ${ }^{34}$

\section{b. Improved information reporting to shrink underreporting tax gap}

Around 80 percent of the tax gap accrues from underreporting of tax liabilities on filed returns. Underreporting is most common in categories of income that are less visible to the IRS—like sole proprietorship income, partnership income, and self-employment returns—as these are subject to relatively little information reporting and not automatically withheld. Substantial revenue could be raised from an increase in information reporting requirements that decreases the ability of tax filers to misreport their income.

\footnotetext{
${ }^{34}$ Note that for all filing categories except individual income tax filers, extra investment would return to 2011 audit rates. For individual filers, extra resources would be tilted toward the wealthy, with the overall audit rate increasing to only 0.7 percent, but the audit rate for those making between \$1 million and \$5 million to 20 percent; \$5 millionand \$10 million to 33 percent; over \$10 million, to 50 percent.
} 


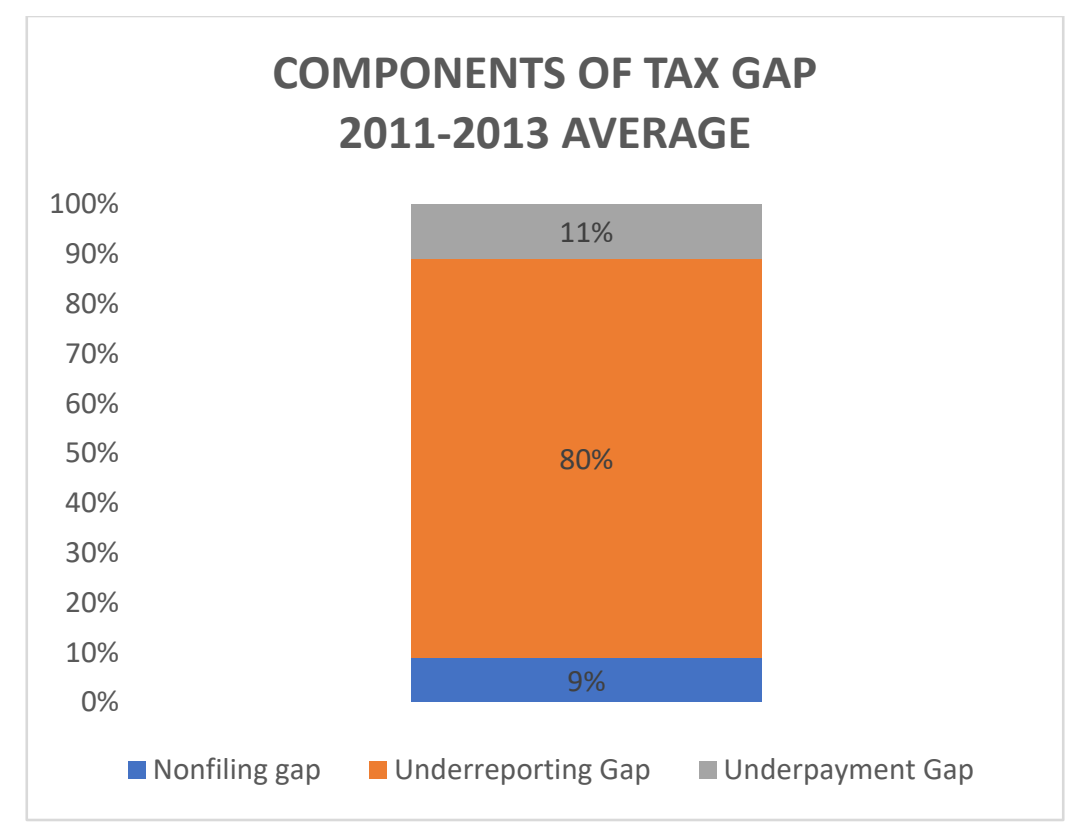

Figure 8: Components of Tax Gap, Across All Tax Categories ${ }^{35}$

We first consider the revenue potential of efforts to shrink the individual income tax gap through increased information reporting. When a salaried employee files her taxes, income is correctly reported and taxes appropriately paid approximately 99 percent of the time. This is because her tax payments are in a sense automated by withholding requirements and easily verified by the simultaneous reporting of her employer. Misreporting remains low (5 percent) for income not automatically withheld but still subject to robust cross-party reporting, like pension income. It jumps to 17 percent for income subject to only light reporting requirements, like partnership income. And it is reaches 55 percent for income subject to essentially no cross-party reporting requirements, like sole proprietor income or rental and royalty income. ${ }^{36}$

Increasing information reporting is regarded as a highly effective way to increase tax compliance. The GAO and IRS suggest that reporting requirements are one of the "few means of sizably increasing the compliance rate.”37 And JCT has highlighted the success of increases in

\footnotetext{
${ }^{35}$ IRS Publication 1415, supra, note 1.

${ }^{36} I d$.

${ }^{37}$ James R. McTigue Jr., “Tax Gap: Multiple Strategies Are Needed to Reduce Noncompliance.” (May 9, 2019) (congressional hearing statement of the GAO director of strategic issues); and Benjamin D. Herndon, "Understanding the Tax Gap and Taxpayer Noncompliance" (May 9, 2019) (written testimony of IRS chief research and analytics officer).
} 
third-party reporting requirements on compliance, noting that a 2011 increase in small business reporting requirements resulted in substantially more accurate reporting of business receipts. ${ }^{38}$

Despite consensus on the desirability of increasing reporting requirements for less transparent income sources, there are relatively few estimates of the potential revenue that could be raised by such reforms. We offer a naïve approach: based on the 2019 tax gap statistics, increasing reporting requirements for individual income categories subject to some information reporting (like partnership/S corporation income) to the “substantial” level of pensions and annuities would generate nearly $\$ 40$ billion in additional tax revenue in 2020. Increasing requirements for income subject to little or no information reporting (like nonfarm proprietor income, rents, and royalties) to the "some information reporting” level would generate an additional \$115 billion in 2020. Between 2020 and 2029, an increase in reporting requirements for the two most opaque income categories would generate nearly $\$ 2$ trillion in tax revenue. ${ }^{39}$

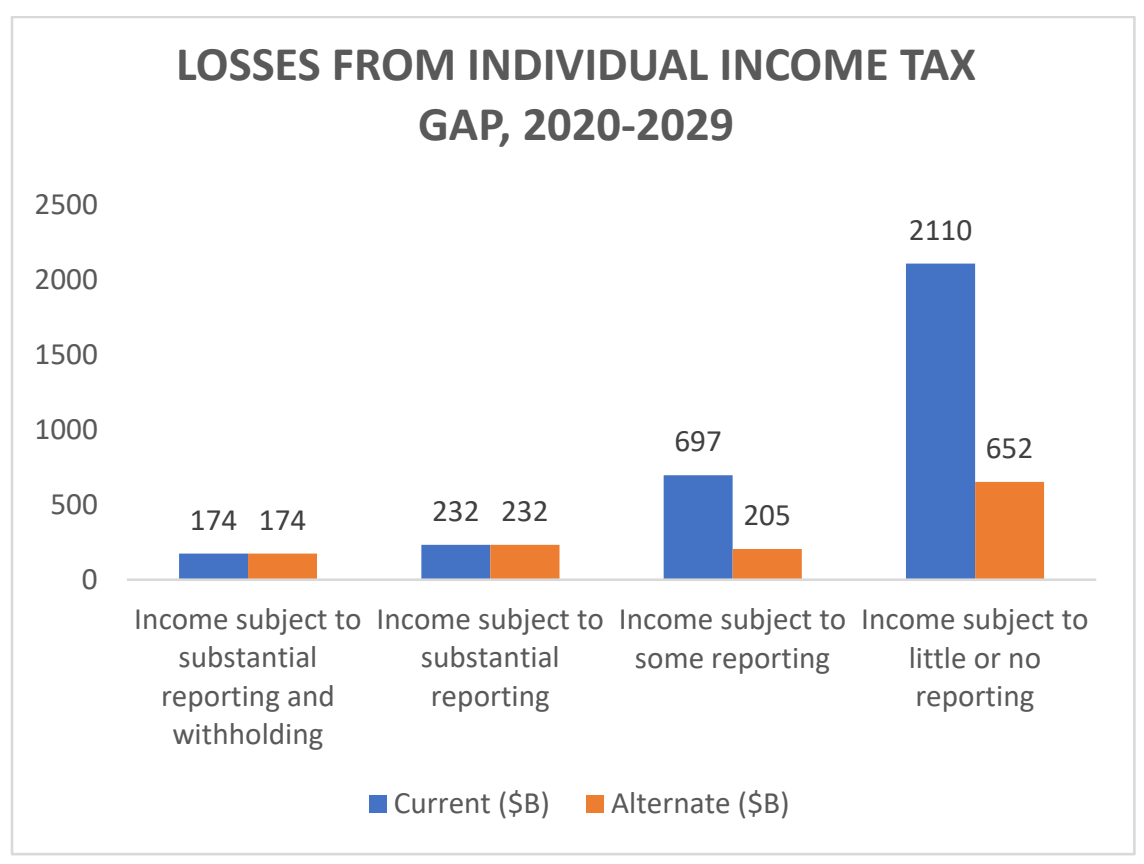

Figure 9: Losses from Tax Gap based on Current Trajectory and Alternate Approach from Increase in Reporting Requirements ${ }^{40}$

\footnotetext{
38 Joint Committee on Taxation. “Overview of the Tax Gap.” JCX-19-19 (May 8, 2019).

${ }^{39}$ IRS Publication 1415, supra note 1.

${ }^{40}$ IRS Publication 1415, supra note 1. To get estimates for years 2020-2029, we first calculate 2018 tax gap numbers by category based on the share of the 2012 individual net tax gap that income that accrues in each of these categories represents. We then age this estimate per the discussion in note 2, supra.
} 
This is an optimistic sum, and it is difficult to be confident about how effective information reporting requirements will be across varied and complex income sources. Additionally, investments made to increase reporting will not reap their full benefits for years, as it will take time to develop and implement changes. But even if in the coming decade an increase in information reporting allows us to capture only 15 percent of the $\$ 2$ trillion estimated, this would mean gains of $\$ 300$ billion in the next decade from individual income tax filers alone.

It is also likely that an increase in information reporting can help address the large and growing self-employment tax gap. ${ }^{41}$ Today, misreported self-employment taxes represent around 10 percent of the tax gap, and non-filed self-employment taxes represent an additional 1 percent. This is at least in part attributable to the growth in self-employment filers in the gig economy. In many cases, platforms do not file information reports unless workers earn at least $\$ 20,000$ annually. Estimates suggest this means that for more than 50 percent of income (by dollars) and 95 percent of returns (by number) the IRS is not provided information by employers about the income earned by workers who file self-employment returns. ${ }^{42}$ Mandating information reporting for all independent contractors would increase compliance. While it is hard to predict the precise magnitude, our reasoning is as follows: self-employment tax misreporting contributes around 11 percent to the net tax gap, relative to around 70 percent for individual filers. We predict an increase in information reporting can shrink the individual tax gap by around 5 percent. A comparable decrease in the self-employment tax gap would mean nearly $\$ 50$ billion in additional revenue in a decade.

\footnotetext{
${ }^{41}$ Self-employment taxes are Social Security and Medicare taxes for individuals who work for themselves, similar to payroll taxes that are automatically withheld from employees.

${ }^{42}$ TIGTA, "Expansion of the Gig Economy Warrants Focus on Improving Self-Employment Tax Compliance” (Feb. 14, 2019).
} 


\begin{tabular}{|lccc|}
\hline & $\begin{array}{c}\text { Share of total tax } \\
\text { gap }\end{array}$ & $\begin{array}{c}\text { Projected tax gap 2020- } \\
\mathbf{2 0 2 9} \text { (billion dollars) }\end{array}$ & $\begin{array}{c}\text { Potential gains } \\
\text { from info } \\
\text { reporting } \\
\text { (billion dollars) }\end{array}$ \\
\hline $\begin{array}{l}\text { Individual } \\
\text { Self-employment }\end{array}$ & $71 \%$ & 5,347 & 300 \\
\hline
\end{tabular}

Table 6: Revenue Raising Potential of Information Reporting Increase for Individual and SelfEmployment Tax Types ${ }^{43}$

\section{c. Technological advancement}

\section{i. IRS relies on antiquated technology}

Although the potential usefulness of technology in helping to identify tax evaders increased dramatically in the last two decades, the IRS has decreased, rather than increased, its IT outlays. Indeed last year, the IRS spent only $\$ 2.5$ billion on IT investments. As a point of comparison, Bank of America spent around \$16 billion, but serves only a quarter of Americans. ${ }^{44}$

The IRS's low budget is not the natural byproduct of modernization decreasing IT costs. Rather, the IRS underinvests in technology, and the effects are evident: by the end of 2017, nearly 60 percent of IRS hardware was past its useable life, and 26 percent of software was two or more releases behind the most up-to-date version. According to the GAO, the IRS Individual Master File and Business Master File systems date back to 1960 and are the two oldest IT systems in the federal government. ${ }^{45}$ Treasury officials warn that outdated technology is a threat to the stability of the tax system: "by analogy, the IRS has erected a 50-story office building on

\footnotetext{
${ }^{43}$ Note that for all filing categories except individual income tax filers, extra investment would return to 2011 audit rates. For individual filers, extra resources would be tilted toward the wealthy, with overall audit rate increasing to only 0.7 percent, but audit rate for those making between $\$ 1$ million and \$5 million to 20 percent; \$5 million and $\$ 10$ million to 33 percent; and over \$10 million to 50 percent.

${ }^{44}$ Between 2010 and 2018, Bank of America spent \$25 billion, or \$3.1 billion per year, on new technology initiatives, which surpasses IRS's technology outlays and "include[s] reworking effectively all of our major systems and adding innovative capabilities, while also building an internal cloud and software architecture for maximum efficiency and speed to market.” Bank of America Annual Report 2018. We are grateful to Charles Rossotti for highlighting this comparison for us.

${ }^{45}$ GAO, "Information Technology: IRS Needs to Take Additional Actions to Address Significant Risks to Tax Procession” (June 2018).
} 
top of a creaky, 60-year foundation, and it is adding a few more floors each year. There are inherent limitations on the functionality of a 60-year-old infrastructure, and at some point, the entire edifice is likely to collapse."46

Outdated technology creates delays for taxpayers: in 2017, the IRS had to extend the filing deadline after a server crash. Additionally, the IRS fails to match in a timely manner many taxpayer filings with information returns filed by third parties which can verify the accuracy of reports.

\section{ii. Greater investment in analytics can increase efficiency and raise revenue}

The IRS piloted the use of data analysis for the identification of suspicious tax returns in 1962. The audit-selection process today remains fairly similar to that first implemented forty years ago - each return is given a score based on the probability of noncompliance, and IRS personnel then manually screen returns to ensure that audit selection is appropriate. ${ }^{47}$

In recent years, the IRS has developed on this front, with early-stage analysis aimed at identifying and quickly resolving deficiencies, before resources are expended on full examinations. These advances have been made possible by the dramatic increase in electronic filings (by 2016, almost 90 percent of returns were filed electronically_a decade earlier, this share was only 54 percent); as well as the greater availability of data, for example from credit card companies and third-party processors on payments routed through their networks. ${ }^{48}$

A recent success is the IRS' return review program (RRP) that automatically identifies discrepancies with information returns to prevent the issuance of invalid refunds. In 2017, RRP saved the IRS $\$ 4.4$ billion $^{49}$ and cost only $\$ 90$ billion. $^{50}$ That is around a 50:1 return.

\footnotetext{
${ }^{46}$ National Taxpayer Advocate Annual Report to Congress 2018 (Feb. 2019).

${ }^{47}$ Kimberly Houser and Debra Sanders, "The Use of Big Data Analytics by the IRS: What Tax Practitioners Need to Know," 128 Journal of Taxation (Feb. 2018).

${ }^{48}$ IRS Office of Compliance Analytics, "Making Analytics Pay, Making Analytics Mainstream," OECD Forum on Tax Administration (Nov. 29, 2011).

${ }^{49}$ GAO, "Tax Fraud and Noncompliance: IRS Could Futher Leverage the Return Review Program to Strengthen Tax Enforcement” (July 2018).

${ }^{50}$ IRS, FY 2019 Capital Investment Plan (undated).
} 
Significant untapped potential remains. The ability to match taxpayer filings with thirdparty information returns increases tax collection: in 2018, the IRS closed 3 million cases in which it identified a discrepancy between the taxpayer's return and third-party information, which resulted in an additional $\$ 5.3$ billion in tax revenue. ${ }^{51}$

However, the actual volume of mismatches is likely significantly larger than the 3 million cases that were closed. This is both because the IRS is currently unable to identify all mismatches; and because it lacks the capacity to collect additional tax revenue even from the discrepancies it identifies. In 2010 when this data was last made available, the IRS identified almost 24 million mismatches on returns, but worked only about 5.3 million (22 percent) of these cases. $^{52}$

The IRS hopes to expand RRP to detect fraud in other filing categories, for example business income and partnership returns, where noncompliance is rising. Beyond refunds, it could also be leveraged to help select the most suspicious returns for examination by improving the match between information reports and taxpayer returns. If the IRS expands information reporting, better matching will have even greater revenue potential.

It is difficult to speculate about potential gains. Assume that marginal investments in information technology, including the expansion of RRP, have much lower returns-perhaps 10:1. This suggests that spending $\$ 10$ billion on investment in a decade would generate $\$ 100$ billion in additional tax revenue.

\section{Benchmarking our estimate with scorekeeper estimates}

There are reasons to believe that the estimates we offer above are too optimistic. We do not take account of the behavioral effects of our proposals: the fact that as enforcement efforts rise, tax evaders will become more sophisticated about sheltering revenue. Additionally, we do not consider the relationship between the different components of our compliance program: For example, greater information reporting will increase voluntary tax compliance, and thus reduce

\footnotetext{
${ }^{51}$ IRS SOI Tax Stats. Table 14, "Information Reporting Program."

${ }^{52}$ National Taxpayer Advocate 2013 Annual Report to Congress (Dec. 31, 2013) ("Fundamental changes to return filing and processing will assist taxpayers in return preparation and decrease improper payments.”)
} 
the returns to additional examinations. And there are potentially diminishing returns to compliance investment.

But there are also reasons to believe our estimates are overly conservative. As one example, we do not consider the revenue that can be generated by a substantial increase in penalties for tax evaders, which would both increase revenue directly and deter illegal avoidance schemes. Additionally, if, as we suspect, the IRS is not currently well-equipped to identify the most suspicious returns for audit attention, then concerns about diminishing marginal returns to extra compliance efforts are less pronounced. This hypothesis is supported by the fact that audit rates and tax collection from examinations decreased 1:1 in recent years.

As a check on our estimation and the feasibility of the substantial investments in compliance we recommend, we compare our estimate of substantial investment in tax compliance to the CBO/JCT's estimate of a much smaller increase in audits and collection efforts. CBO recently estimated that a \$20 billion investment in 2019 would generate \$55 billion in additional tax collections between 2019 and 2028. ${ }^{53}$ At first glance, our estimates appear substantially more optimistic than this.

This is largely because the CBO approach is based on a program that is far more modest in scale and scope. Returning the IRS to historical budget levels (as a share of total collections) would involve an expansion of over four times that which the CBO proposes. Additionally, the CBO primarily focuses on returns to more aggressive auditing overall. The approaches we consider are better targeted: we consider an expansion of IRS high-income audits where returns are highest. They are also broader: we also consider an increase in IT investment and information reporting that the $\mathrm{CBO}$ does not, although it acknowledges this is likely to be an efficient way to raise additional tax revenue.

Still, the CBO estimate provides a useful baseline for extrapolation. If the IRS budget increased to the 2010 share of gross collections, this would mean nearly $\$ 100$ billion in greater IRS expenditure between 2020 to 2029. The Treasury reports that indirect effects of compliance-

\footnotetext{
${ }^{53}$ CBO, “Options for Reducing the Deficit: 2019 to 2028. Increase Appropriations for the Internal Revenue Service’s Enforcement Initiatives,” (Dec. 13, 2018).
} 
oriented investment are likely to be more than three times as large. ${ }^{54}$ Augmenting the CBO estimate to incorporate deterrence effects results suggests that restoring IRS budget outlays to historical levels would generate around $\$ 1.1$ trillion. This is quite close to our estimate (\$1.15 trillion) of the total revenue-raising potential of our compliance proposals.

This comparison is in some sense spurious because our approach above does not consider indirect deterrence effects, but this omission may well be counteracted by overly optimistic estimation. On balance, the $\mathrm{CBO}$ estimate does not lead us to doubt that a substantial investment in the IRS has the potential to shrink the tax gap by at least $\$ 1$ trillion in the coming decade.

\begin{tabular}{|ll|}
\hline \multicolumn{2}{|c|}{ Revenue from Increasing IRS Budget, 2020-2029 } \\
\hline A. Increase in Budget (2020-2029) & $\$ 100$ billion \\
B. Direct Effect (= A x \$2.75, extrapolating CBO estimate) & $\$ 275$ billion \\
C. Indirect Effect (= B x 3, per Treasury) & $\$ 825$ billion \\
D. Total Impact ( B + C) & $\$ 1.1$ trillion \\
E. Net of Costs (= D - A) & $\sim \$ 1$ trillion \\
\hline
\end{tabular}

Table 7: Revenue Raising Potential from Substantial Enforcement Investment ${ }^{55}$

\section{a. Issues with budget scorekeeping of compliance initiatives}

As the above illustrates, we offer only rough back-of-the-envelope revenue approximations. Before policy is pursued in this vein, it will be important to have professional scorekeepers like those at the CBO, JCT, and other major agencies weigh in on the likely returns to investment in the tax compliance proposals we outline.

It is important to highlight that these agencies’ scorekeeping guidelines limit their ability to account for revenue gains from compliance efforts when they provide official scores of proposals to increase the IRS' budget. These guidelines were put into place in response to legitimate criticisms of congressional leaders' reliance on "tax compliance initiatives" to stopgap last hour budget gaps. This practice became discredited, and the revenue from increased enforcement efforts came to be excluded from official scorekeeping. To the extent possible, professional

\footnotetext{
${ }^{54}$ The IRS reports in its 2019 budget request that the returns on enforcement are "likely understated, since the ROI estimate does not include the revenue effect of the indirect deterrence value of IRS enforcement programs, which is conservatively estimated to be at least three times the direct revenue effect."

${ }^{55}$ See note 53, supra. Direct effects estimated based on CBO revenue option.
} 
scorekeepers still provide Congress with information on potential revenue effects ${ }^{56}$ — for example by estimating "nonscorable” gains from greater enforcement efforts. But what is counted, counts. When credit is not given for revenue that will be collected from increased spending on compliance efforts, it is unsurprising that such spending is neglected. The constraints imposed by the budget scorekeeping guidelines in this context relate to a broader debate about what kind of feedback effects should be considered in revenue estimates for changes to federal budget policy, long an area of controversy. This paper suggests that the revenue gains from investments in tax compliance are likely to be substantial — and thus the consequences of the scoring guidelines significant, with stakes in the same range as those at play in the debate on dynamic scoring.

\section{Conclusion}

Our hope is for this short paper to highlight that decisions about the scale of the IRS are comparable revenue significance to much debate about changes in tax provisions. Further, improvements in revenue collection from better tax enforcement have the potential to produce efficiency gains, by reducing the diversion of resources into areas where avoidance is easy. Compliance efforts will also increase the progressivity of the tax system, because noncompliance is greatest among high-income taxpayers.

${ }^{56}$ JCT and CBO, "Factors Affecting Revenue Estimates of Tax Compliance Proposals,” JCX-90-16 (Nov. 29, 2016). 